\title{
新規トロンボキサン $\mathrm{A}_{2}$ 拮抗薬，S-145 の 血小板凝集に対する作用
}

\author{
嘉久志寿人, 四家勉, 内田 清久 \\ 塩野義製薬 (株) 研究所* \\ （昭和63年12月 1 日 [特]）
}

\begin{abstract}
要約 : S-145, ( \pm )-5(Z)-7-(3-endo-phenylsulfonylamino[2.2.1]bicyclohept-2-exo-yl)heptenoic acid は in vitro で, ヒト血小板の arachidonic acid (AA), 9,11-methanoepoxy- $\mathrm{PGH}_{2}$ (U46619), collagen および ADP (二次凝集) 凝集を阻害し, その平均 $50 \%$ 阻害濃度はそれぞれ $0.25,0.34,0.22$ および $0.08 \mu \mathrm{M}$ であった. S-145 のヒト血小板 AA および U46619 凝集の阻害活性は ONO-3708 の約 2 倍, SQ 29,548 の約 $1 / 7 \sim 1 / 14$, モルモット血小板では, 前者の約 7 倍, 後者の $1 / 3 \sim 1 / 7$ であった. しか し, ウサギ血小板の凝集に対しては ONO-3708 おょび SQ 29,548 の作用が特に弱く, S-145 の作用は ONO-3708の250 800倍以上, SQ 29,548 の 1〜 7 倍であった. S-145をモルモットに $0.1 \mathrm{mg} / \mathrm{kg}$, 経口 投与すると 30 分後および 60 分後の AA 凝集は完全に阻害されたが， 3 時間後および 6 時間後では有意な 阻害がみられなかった．S-145 の経口60分後における AA および collagen 凝集の阻害はそれぞれ 0.01 $\mathrm{mg} / \mathrm{kg}$ 以上拉よび $0.03 \mathrm{mg} / \mathrm{kg}$ 以上の $\mathrm{S}-145$ 投与で有意であった. モルモット血小板の $\mathrm{AA}$ 抢よび collagen 凝集に対する S-145 の経口投与による阻害作用は ONO-3708 およよ゙ SQ 29,548 の約30 300 倍, aspirin の 300 1000倍であった. 以上の成績から, S-145 は強い TXA 2 拮抗阻害作用を示し, 経口 投与で強い血小板凝集阻害作用を示す化合物であると結論される.
\end{abstract}

\section{緒 言}

血小板で，アラキドン酸から生成されるトロンボキサ ン $\mathrm{A}_{2}\left(\mathrm{TXA}_{2}\right)$ は強力な血小板凝集作用と平滑筋収縮作 用を有している( ${ }^{123}$. 従って, TXA 2 は心血管系の血栓 症や狭心症さらには気管支喘息などの病態に関与してい ると考觉られている2,4,5). そのよらなことから， $\mathrm{TXA}_{2}$ 生合成阻害薬あるいは拮抗薬の開発研究はとれら病態の 予防薬あるいは治療薬として注目されており, 臨床上に おける，それらの薬物はシクロオキシゲナーゼ阻害薬, $\mathrm{TXA}_{2}$ 生合成酵素阻害薬, $\mathrm{TXA}_{2} レ$ レプタ一拮抗薬の 主に， 3 つに分類される ${ }^{6)}$.

新規 $\mathrm{TXA}_{2}$ レセプター拮抗薬, S-145, ( \pm )-5(Z)-7(3-endo-phenylsulfonylamino[2.2.1]bicyclohept-2-cxo$\mathrm{yl}$ )heptenoic $\mathrm{acid}^{7)}$ は血小板および培養血管平滑筋細 胞および内皮細胞の $\mathrm{TXA}_{2} / \mathrm{PGH}_{2}$ レセプターに強い拮 抗作用を有している8 11). 本報告は, S-145 の血小板凝 集に対する作用を他の $\mathrm{TXA}_{2}$ 捛抗薬, ONO-3708 ${ }^{122}$, SQ 29,54813)，およびシクロオキシゲナーゼ阻害薬であ る $\operatorname{aspirin}^{14)}, \mathrm{TXA}_{2}$ 生合成醳素阻害薬である dazoxi-

* 㞼553 大阪市福島区鷑洲 5 丁目 12-4 ben ${ }^{15)}$ などと, in vitro および ex vivo で比較検討し たものである.

\section{実験材料および実験方法}

\section{1. 使用薬物}

S-145 の化学構造式は図1亿示すが，比較薬には ONO-3708 および（+）SQ 29,548 を用いた.

in vitro 試験での S-145（ナトリウム塩）および ONO-3708 (ナトリウム塩) は生理食塩液に溶解し, SQ 29,548 は dimethylsulfoxide (DMSO) 飞溶解し た. aspirinは $400 \mathrm{mM}$ エタノール溶液を使用時に 30 $\mathrm{mM}$ トリス塩酸緩衝液 $(\mathrm{pH} 7.4)$ で希釈し, dazoxiben は前記の緩衝液に溶解した。

ex vivo 試験での S-145, SQ 29,548, aspirin および dazoxiben は $5 \%$ アラビアゴム溶液に懸濁または溶解 乙, ONO-3708（ナトリウム塩）は生理食塩液に溶解し た. 投与容量は $2 \mathrm{ml} / \mathrm{kg}$ とした.

\section{2. 使用動物}

モルモット（Slc-ハートレイ系，雄性，8～9.5週龄, 体重 480 ６00 g ）拉よびゥサギ（NIBS-JW, 雄性, 体 重 $2.2 \sim 2.7 \mathrm{~kg}$ ）を使用した. 


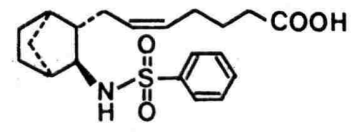

$S-145$

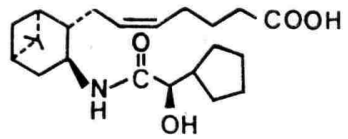

ONO-3708

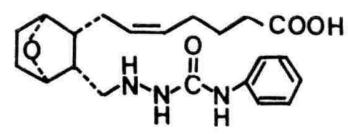

SQ 29,548

Fig. 1 Chemical structures of S-145, ( \pm )-5(Z)-7-(3-endo-phenylsulfonylamino [2.2.1] bicyclohept-2-exo-yl)heptenoic acid and other thromboxane $\mathrm{A}_{2}$ antagonists.

3. $ヒ 卜$

健常成人男子 30 例（25～57歳）で検討した.

4. 採 血

動物はペントバルビタールナトリウム（Somunopentyl；Pitman Moore) 麻酔下で腹部大動脈より, ヒトは早朝空腹時に肘静脈より $3.8 \%$ クエン酸ナトリウ ム 1 容に対し血液 9 容の割合で採血した.

5. 多血小板血漿 (Platelet-rich plasma; PRP) お よびそ血小板血漿 (Platelet-poor plasma; PPP) の調製

ヒト血液は $22^{\circ} \mathrm{C}, 180 \times \mathrm{g}, 10$ 分, モルモット血液は $180 \times \mathrm{g}, 15$ 分, ウサギ血液は $200 \times \mathrm{g}, 10$ 分遠心し上清の PRP を採取した. 残りの血液は $22^{\circ} \mathrm{C}, 3000 \mathrm{rpm}, 10$ 分 遠心し PPP を得た. PRP の血小板数はュールターカ ウンターで測定し，モルモットおよびウサギの場合は血 小板数が $50 \sim 60 \times 10^{4} / \mu 1$ になるように PPP で希釈調 製した。

\section{6. 血小板凝集惹起物質の調製}

アラキドン酸（AA，ナトリウム塩, Sigma) および ADP (Pharmacia) は生理食塩液に溶解し, collagen （Hormon-Chemie）は生理食塩液に懸濁し，9,11methanoepoxy- $\mathrm{PGH}_{2}$ (U46619) は $10 \mathrm{mM}$ エタノー ル溶液を生理食塩液で希釈（エタノール終濃度, 0.04 \%)した.

\section{7. 血小板凝集の測定}

血小板の凝集反応は Born ${ }^{16)}$ の方法に準じて，血小 板凝集計 (AUTO-RAM 61, 理化電機工業) を用いて 測定した. in vitro 試験は PRP $230 \mu 1$ を $37^{\circ} \mathrm{C}, 1$ 分間摫拌 $(1200 \mathrm{rpm})$ 予備加温後, 被検化合物溶液（生理食塩液 および緩衝液に溶解した場合には $10 \mu \mathrm{l}, \mathrm{DMSO} に$ 溶 解した場合には, その溶液 $1 \mu \mathrm{l}$ と生理食塩液 $9 \mu \mathrm{l})$ を 加光, 2 分後に血小板凝集惹起物質 $10 \mu \mathrm{l}$ を添加し, 血 小板の凝集により生じた透光度の変化を経時的に記録し た ${ }^{17)}$.

ex vivo 試験では, PRP $240 \mu 1$ に凝集惹起物質 $10 \mu 1$ を添加し, in vitro の場合と同様に測定した.

血小板の凝集率は PRP および PPP の透光度とそ れぞれ $0 \%$ および $100 \%$ とし，凝集剤添加後の最大透光 度を最大凝集率とした. 血小板の凝集阻害率は対照群の 最大凝集率に対する薬剂添加群の最大凝集率の割合から 求めた.

\section{実 験 結 果}

\section{1. in vitro での血小板凝集に対する作用}

ヒト血小板の AA, U46619, collagen 凝集および ADP の二次凝集に対する S-145 の50\%阻害濃度 (IC50) を表 1 に示した。

S-145 は AA, U46619 および collagen 凝集に対し てほぼ同程度の濃度で阻害を示し，その平均 IC50 はそ れぞれ $0.25 ， 0.34$ および $0.22 \mu \mathrm{M}$ であった. 一方, $\mathrm{ADP}$ の二次凝集の阻害はや〉強く, $0.08 \mu \mathrm{M}$ であっ た.

図 2 は, ヒト 8 例の U46619 凝集に対する S-145 の 阻害率を示す成績であるが，個体により阻害濃度には 2 〜 4 倍の差がみられた. 
Table 1 Inhibitory effect of S-145 on arachidonic acid-, U46619-, collagenand ADP-induced human platelet aggregation in vitro

\begin{tabular}{lccc}
\hline \multicolumn{2}{l}{ Aggregating inducers and concentration } & $\mathrm{n}$ & IC50 $(\mu \mathrm{M})$ \\
\hline Arachidonic acid & $500 \mu \mathrm{M}$ & 8 & $0.25 \pm 0.06$ \\
& & & $(0.07 \sim 0.51)$ \\
9, 11-Methanoepoxy-PGH 2 & $4 \mu \mathrm{M}$ & 8 & $0.34 \pm 0.05$ \\
(U46619) & & & $(0.17 \sim 0.54)$ \\
Collagen & $0.5 \mu \mathrm{g} / \mathrm{ml}$ & 5 & $0.22 \pm 0.04$ \\
& & & $(0.11 \sim 0.35)$ \\
ADP (2 ${ }^{\circ}$ Phase) & 2 or $3 \mu \mathrm{M}$ & 4 & $0.08 \pm 0.04$ \\
& & & $(0.04 \sim 0.19)$ \\
\hline
\end{tabular}

Each value represents the mean \pm S.E. (range of minimum to maximum of IC50 value ).

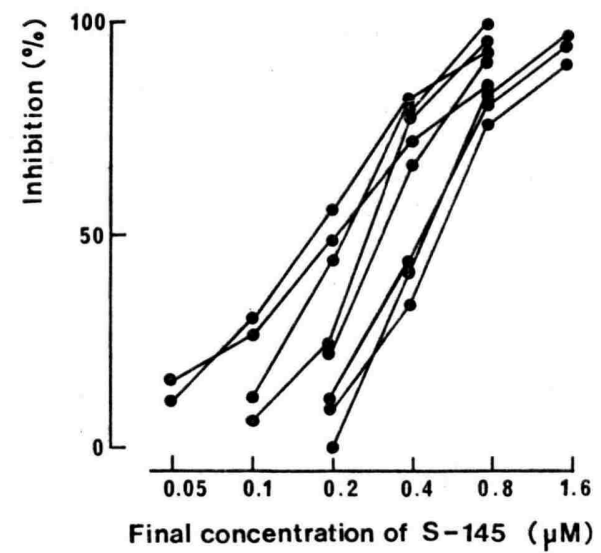

Fig. 2 Inhibitory effect of S-145 on U46619 $(4 \mu \mathrm{M})$-induced human platelet aggregation in vitro. Each point represents the mean value of duplicate measurements on 8 volunteers shown in Table 1.
S-145, ONO-3708 および SQ 29,548 のヒト，モル モットおよびゥサギ血小板の AA おょよび U46619 凝集 に対する平均 IC50 值を表 2 亿示した.

ヒト血小板凝集に対する S-145 の阻害作用は ONO3708 の約 2 倍, SQ 29,548 の約1/7〜1/14であった.

ヒトとほぼ同様な成績はモルモットでも得られたが， ウサギの場合には S-145 に比べて ONO-3708 および SQ 29,548 の作用は弱く, ヒトやモルモットでの阻害濃 度に比べてはるかに高濃度を要した。

\section{2. ex vivo での血小板凝集に対する作用}

モルモットに S-145を $0.1 \mathrm{mg} / \mathrm{kg}$ 経口投与した場合 の $\mathrm{AA}$ 凝集の経時変化を図 3 に示した.

投与 30 分後打よび 60 分後の $\mathrm{AA}$ 凝集は完全に阻害さ れたが， 3 時間後には有意な阻害はみられず，6時間後 には投与前の值まで回復した。モモルモット血小板の AA 凝集に対する S-145 の用量作用関係を図 4 亿示した。

Table 2 Inhibitory effects of S-145, ONO-3708 and SQ29,548 on arachidonic acid- and U46619-induced human, guinea pig and rabbit platelet aggregation in vitro

\begin{tabular}{|c|c|c|c|c|c|}
\hline \multirow{3}{*}{$\begin{array}{l}\text { Species } \\
\text { Human }\end{array}$} & \multirow{2}{*}{\multicolumn{2}{|c|}{$\begin{array}{l}\text { Aggregating inducers and } \\
\text { concentration }\end{array}$}} & \multicolumn{3}{|c|}{ IC50 (mean, $\mu \mathrm{M}$ ) } \\
\hline & & & \multirow{2}{*}{$\begin{array}{c}\text { S-145 } \\
0.25(8) \\
0.42(3)^{\mathrm{a}}\end{array}$} & \multirow{2}{*}{$\begin{array}{l}\text { ONO-3708 } \\
0.58(3)^{\mathrm{a}}\end{array}$} & \multirow{2}{*}{$\begin{array}{l}\mathrm{SQ} 29,548 \\
0.018(4)\end{array}$} \\
\hline & Arachidonic acid & $500 \mu \mathrm{M}$ & & & \\
\hline & U46619 & $4 \mu \mathrm{M}$ & $\begin{array}{l}0.34(8) \\
0.35(3)^{\mathrm{a}}\end{array}$ & $0.69(4)$ & $\begin{array}{l}0.058(3) \\
0.045(3)^{\mathrm{a}}\end{array}$ \\
\hline Guinea pig & $\begin{array}{l}\text { Arachidonic acid } \\
\text { U46619 }\end{array}$ & $\begin{array}{r}100 \mu \mathrm{M} \\
4 \mu \mathrm{M}\end{array}$ & $\begin{array}{l}0.15(5) \\
0.12(4)\end{array}$ & $\begin{array}{l}0.98(5) \\
0.91(4)\end{array}$ & $\begin{array}{l}0.023(5) \\
0.045(5)\end{array}$ \\
\hline Rabbit & $\begin{array}{l}\text { Arachidonic acid } \\
\text { U46619 }\end{array}$ & $\begin{array}{r}200 \mu \mathrm{M} \\
4 \mu \mathrm{M}\end{array}$ & $\begin{array}{l}0.93(7) \\
0.27(4)\end{array}$ & $\begin{array}{rr}>800 & (5) \\
66.7 & (4)\end{array}$ & $\begin{array}{ll}6.56 & (4) \\
0.23 & (4)\end{array}$ \\
\hline
\end{tabular}

Each value represents the mean value of IC50. ( ): Number of cases. a: Each value represents the mean of triplicate measurements with the pooled PRP of 3 volunteers. 


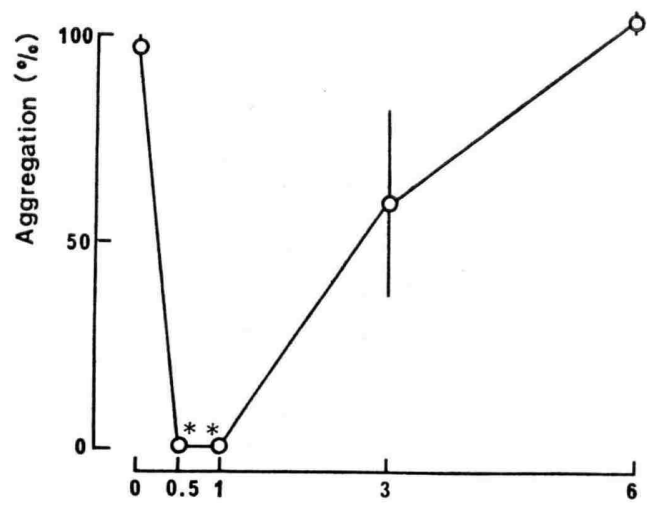

Time in hrs after S-145 administration (p.o.)

Fig. 3 Effect of S-145 on arachidonic acid $(100 \mu \mathrm{M})$-induced guinea pig platelet aggregation. Blood was collected at $30 \mathrm{~min}$ and 1,3 and $6 \mathrm{hr}$ after a single oral administration of $0.1 \mathrm{mg} / \mathrm{kg}$ of $\mathrm{S}-145$ suspended in $5 \%$ arabic gum solution. Each point and bar represent the mean $\pm \mathrm{S}$.E. of 5 guinea pigs. $* \mathrm{P}<0.05$, significantly different from the control $(0 \mathrm{hr})$.

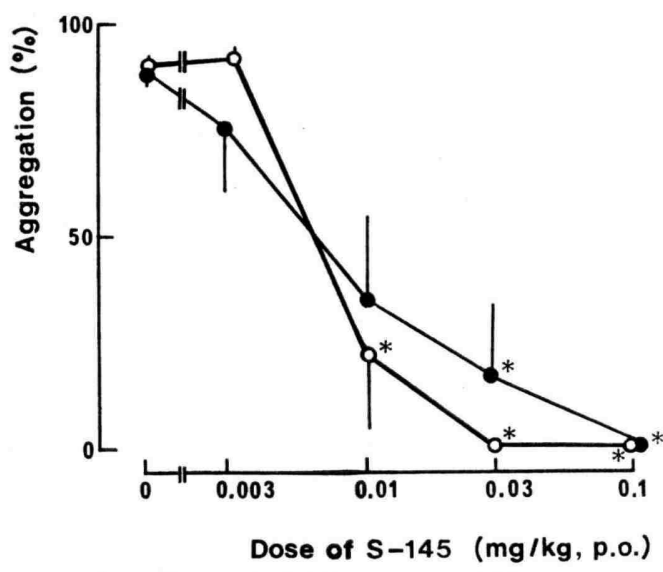

Fig. 4 Effect of S-145 on arachidonic acid $(100 \mu \mathrm{M})$-induced guinea pig platelet aggregation. Blood was collected $30 \mathrm{~min}$ (-O) and $60 \mathrm{~min}(\mathrm{O}-\mathrm{O})$ after a single oral administration of S-145 suspended in 5\% arabic gum solution. Each point and bar represent the mean $\pm \mathrm{S}$.E. of 5 guinea pigs. $* \mathrm{P}<0.05$, significantly different from the control.

S-145 の経口投与 30 分後と 60 分後の AA 凝集阻害に は大差はみられないが, 投与 60 分後の作用がや〉強く, その最少阻害用量は $0.01 \mathrm{mg} / \mathrm{kg}$ であった.

図 5 は，モルモット血小板の AA および collagen 凝 集に対する S-145 の用量作用関係を示す成績である.

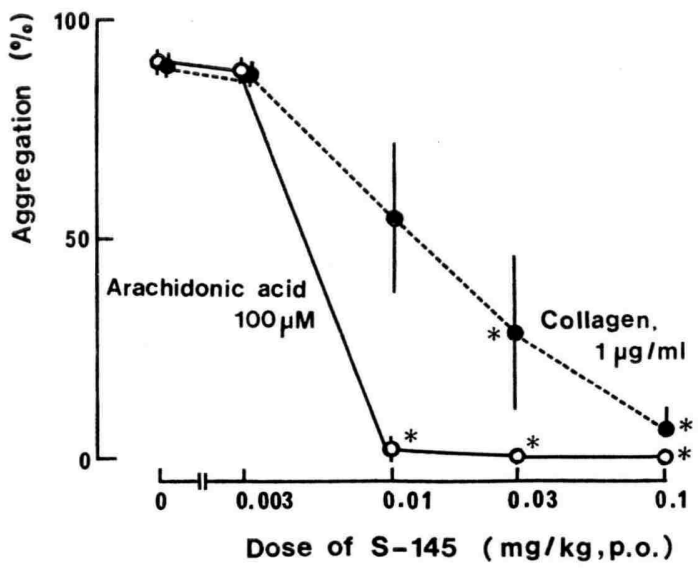

Fig. 5 Effect of S-145 on arachidonic acid- and collagen-induced guinea pig platelet aggregation. Blood was collected $60 \mathrm{~min}$ after a single oral administration of $\mathrm{S}-145$ suspended in 5\% arabic gum solution. Each point and bar represent the mean \pm S.E. of 5 guinea pigs. $* \mathrm{P}<0.05$, significantly different from the control.

経口投与 60 分後に拈ける AA 凝集阻害を S-145 は 0.01 $\mathrm{mg} / \mathrm{kg}$ 以上, collagen 凝集阻害を $0.03 \mathrm{mg} / \mathrm{kg}$ 以上で 有意に阻害した.

ONO-3708 および SQ 29,548 の経口投与 60 分後に おける凝集阻害作用を表 3 に示した.

両化合物とも AA 凝集に対して $0.3 \mathrm{mg} / \mathrm{kg}$ 以上で阻 害した. しかし, collagen 凝集に対しては作用が弱く, ONO-3708 は $10 \mathrm{mg} / \mathrm{kg}$ で阻害したが SQ 29,548 は $1 \mathrm{mg} / \mathrm{kg}$ でも阻害しなかった.

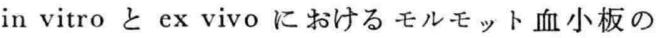
AA および collagen 凝集に対する S-145 と他の薬物 の作用を比較した成績を表 4 に示した.

in vitro での血小板凝集阻害作用は SQ 29,548 が最 も強いが, ex vivo（経口投与）では S-145 が最も強 く, その最少有効量で比べると S-145 は ONO-3708 お よび SQ 29,548 の約 30〜300倍, aspirin の 300〜1000 倍であった. 一方, dazoxiben は $10 \sim 300 \mathrm{mg} / \mathrm{kg}$ 投与 でも阻害を示さなかった.

\section{考察}

新規 $\mathrm{TXA}_{2}$ レセプター拮抗薬である $\mathrm{S}-145$ の血小板 凝集に対する作用を ONO-3708 および SQ 29,548 と in vitro および ex vivo で比較検討した.

$\mathrm{S}-145$ はヒトおよびラット血小板の $\mathrm{TXA}_{2} / \mathrm{PGH}_{2}$ レ セプターへの [ $\left.{ }^{3} \mathrm{H}\right] \mathrm{U} 46619$ の結合に対し SQ 29,548 よ 
Table 3 Effects of ONO-3708 and SQ29,548 on arachidonic acid- and collagen-induced guinea pig platelet aggregation

\begin{tabular}{lccc}
\hline & Dose & \multicolumn{2}{c}{ Platelet aggregation $(\%)$} \\
\cline { 3 - 4 } & $(\mathrm{mg} / \mathrm{kg})$ & $\begin{array}{c}\text { Arachidonic acid } \\
(100 \mu \mathrm{M})\end{array}$ & $\begin{array}{c}\text { Collagen } \\
(1 \mu \mathrm{g} / \mathrm{ml})\end{array}$ \\
\hline Control & Vehicle & $\left.94.9 \pm 2.3^{\mathrm{a}}\right)$ & $93.2 \pm 2.2$ \\
ONO-3708 & 0.1 & $92.6 \pm 1.5$ & $88.5 \pm 3.6$ \\
& 0.3 & $2.7 \pm 2.2^{*}$ & $88.3 \pm 4.7$ \\
& 1 & $0.6 \pm 0.4^{*}$ & $72.2 \pm 18.1$ \\
& 3 & 0 & $71.6 \pm 9.1$ \\
Control & 10 & 0 & 0 \\
SQ29,548 & Vehicle & $91.5 \pm 1.3$ & $92.2 \pm 1.2$ \\
& 0.03 & $92.2 \pm 0.9$ & $90.9 \pm 0.7$ \\
& 0.1 & $38.3 \pm 20.6$ & $87.0 \pm 1.5$ \\
& 0.3 & $21.5 \pm 16.5^{*}$ & $68.4 \pm 17.2$ \\
& 1 & 0 & $66.8 \pm 17.0$ \\
\hline
\end{tabular}

Blood was collected 60 min after a single oral administration of ONO-3708 dissolved in saline or SQ29,548 suspended in 5\% arabic gum solution. Each value represents the mean \pm S.E. of 5 guinea pigs. ${ }^{*} \mathrm{P}<0.05$, significantly different from the control.

Table 4 Effects of S-145, ONO-3708, SQ29,548, aspirin and dazoxiben on arachidonic acid- and collagen-induced guinea pig platelet aggregation in vitro and ex vivo

\begin{tabular}{|c|c|c|c|c|}
\hline & \multicolumn{2}{|c|}{$\begin{array}{c}\text { In vitro } \\
\text { IC50 }(\mu \mathrm{M})\end{array}$} & \multicolumn{2}{|c|}{$\begin{array}{c}\text { Ex vivo } \\
\text { Minimum effective dose } \\
(\mathrm{mg} / \mathrm{kg} \text {, p.o. })\end{array}$} \\
\hline & $\begin{array}{c}\text { Arachidonic acid } \\
100 \mu \mathrm{M}\end{array}$ & $\begin{array}{l}\text { Collagen } \\
1 \mu \mathrm{g} / \mathrm{ml}\end{array}$ & $\begin{array}{c}\text { Arachidonic acid } \\
100 \mu \mathrm{M}\end{array}$ & $\begin{array}{l}\text { Collagen } \\
1 \mu \mathrm{g} / \mathrm{ml}\end{array}$ \\
\hline S-145 & 0.15 & 0.31 & 0.01 & 0.03 \\
\hline ONO-3708 & 0.98 & 1.87 & 0.3 & 10 \\
\hline SQ29,548 & 0.023 & 0.034 & 0.3 & $>1$ \\
\hline Aspirin & 126.4 & 80.3 & 10 & 10 \\
\hline Dazoxiben & 2094 & 1947 & \multicolumn{2}{|c|}{ no inhibition at $10 \sim 300$} \\
\hline
\end{tabular}

Each value represents the mean value of 4 to 5 guinea pigs.

りも強く, ONO-3708 よりもさらに強い拮抗作用を有 している8,9). なお, Kattelman $5^{18)}$ 数種 $\mathrm{TXA}_{2}$ 拮 抗薬の作用を比較し, SQ 29,548 は ONO-3708 より も強い拮抗作用を示すことを報告している.ささらに, S-145 はラットの培養血管平滑筋細胞および内皮細胞 の $\mathrm{TXA}_{2} / \mathrm{PGH}_{2}$ レセプターに対しても SQ 29,548 や ONO-3708 よりも強い拮抗を示し, その作用は U46619 によるラット動脈の収縮に対する抑制作用の強さとも相 関している10,11).

S-145 は in vitro でヒト血小板の AA, U46619, collagen 凝集拈よび ADP の二次凝集を阻害し，その IC50 はそれぞれ $0.25 ， 0.34 ， 0.22$ および $0.08 \mu \mathrm{M} て ゙$ あった.

一方, 比較薬に用いた ONO-3708 の血小板凝集阻 害の IC50は $0.21 \mu \mathrm{M}^{12)}$, SQ 29,548 の AA および $\mathrm{U} 46619$ 凝集阻害はそれぞれ 0.012 および $0.05 \mu \mathrm{M}^{13)}$ と報告されている.

in vitro 飞怙ける S-145 の血小板凝集阻害作用は SQ 29,548 の 1/7〜1/14, ONO-3708 の約 2 倍であった が，本成績に抢ける SQ 29,548 の IC50 值は Ogletree 
ら ${ }^{123}$ の成績とよく一致していた. また，モルモットでも ヒトにおける成績にほぼ一致する成績が得られた，しか し，ウサギ血小板の凝集阻害作用にはヒトと差異がみら れ, 特に ONO-3708 の作用はヒトやモルモットに比べ て極めて弱かった. また, SQ 29,548 も ONO-3708 と ほぼ同様の成績であった，従って，これら両化合物の血 小板凝集阻害作用には種属差があるが，S-145 の作用に は種属間に大差がみられない. Narumiya ら ${ }^{19)}$ および Hanasaki and Arita9) は ONO-11120 および ONO3708 のピナン化合物はヒト血小板に比べてウサギ血小 板のレセプターへの結合能拈よび血小板凝集阻害作用は 極めて弱いことを指摘している. 従って，血小板凝集に 関係する実験モデルにウサギを用いると，ONO-3708 やSQ 29,548 の作用はヒトの成績に比べて弱く評価さ れる.

このような事実から，本報告の ex vivo の実験では いずれの化合物ともとトに近い成績（IG50）を示した モルモットを選んだ.

モルモットに S-145を $0.1 \mathrm{mg} / \mathrm{kg}$ 経口投与すると 30 分後および 60 分後の AA 凝集は完全に阻害されたが, 投与 3 時間および 6 時間後では有意な阻害はみられなか った。な拉，本報告には示さなかったが，ONO-3708 も $1 \mathrm{mg} / \mathrm{kg}$ 経口投与で $\mathrm{S}-145$ の $0.1 \mathrm{mg} / \mathrm{kg}$ 飞相当す る成績が得られた。

そこで, 経口投与60分後における AA および collagen 凝集に対する S-145, ONO-3708, SQ 29,548, aspirin および dazoxiben の作用を比較したが，S-145 が最も 強い阻害作用を示し, AA および collagen 凝集に対す る最少有効量で比べると，S-145 は ONO-3708 おょよ゙ SQ 29,548 の 30〜300倍, aspirin の 300〜1000倍であ った. in vitro で強力な阻害作用を示した SQ 29,548 は経口投与では作用は弱かった．これは，化合物の代謝 に関係するのかも知れない。

ところで，AA による凝集は濃度にもよるが，本実験 で用いた AA 濃度では添加後直ちに凝集が開始する が, ONO-3708 $(0.3 \sim 3 \mathrm{mg} / \mathrm{kg})$ おょび SQ 29,548 $(0.3 \sim 1 \mathrm{mg} / \mathrm{kg})$ 投与群では AA 添加後一旦弱い凝集が 起り解離したのち, あるいは全く凝集が起らない場合で も， 3〜4 分以上攪抖を継続すると凝集が起った. すな わち, AA 添加後凝集の遅延が観察された. しかし, ONO-3708 $10 \mathrm{mg} / \mathrm{kg}$ 投与群では完全に阻害された.

このような現象は in vitro でも観察されたが, ヒト 血小板ではほとんどみられない現象であることからモル モットに特有なものではないかと考觉られる.一方,
$\mathrm{S}-145$ の場合にはその最少有効量に近い $0.01 \mathrm{mg} / \mathrm{kg}$ 投 与群でまれにみられたが，その発現頻度は ONO-3708 やSQ 29,548 に比べて少なかった。このよらな現象 は, 血小板のレセプターへの結合能, 解離速度および $\mathrm{TXA}_{2}$ 産生能などがその要因として考えられるが，現 時点では明かでない.なお, 本成績では $\mathrm{AA}$ 添加から 3 分までの最大㠜集率を指標とした.

$\mathrm{TXA}_{2}$ 拮抗薬の AA 凝集と collagen 凝集に対する 阻害用量は ex vivo では後者の場合により高用量を要 した. 例えば, 両凝集阻害の最少有効量で比較すると S-145 は 3〜 10倍, ONO-3708 は30倍, SQ 29,548 は 3 倍以上であり, この阻害の用量差は in vitro での同 濃度の AA および collagen 凝集に対する阻害の濃度 差（1.5〜2 倍）よりも大きかった. モルモットでの ex vivo と in vitro での差がなぜ起るか未だ明かでない.

しかし, aspirin の場合には両凝集とも $10 \mathrm{mg} / \mathrm{kg}$ で完 全に阻害されたが 1 および $3 \mathrm{mg} / \mathrm{kg}$ では阻害されず用 量差は認められなかった.

$\mathrm{TXA}_{2}$ 生合成酵素阻害薬である dazoxiben (UK-37, 248-01) は，モルモット血小板の AA および collagen 凝集に対し in vitro で約 $2 \mathrm{mM}$ といった高濃度でし か阻害を示さなかった，さらに，モルモットに 10〜300 $\mathrm{mg} / \mathrm{kg}$ 経口投与しても 60 分後の AA および collagen 凝集には全く影響を与兄なかった.

ところで, dazoxiben の $\mathrm{TXA}_{2}$ 生合成酵素阻害の IC50 は $3 \times 10^{-9} \mathrm{M}$ であり, ヒトに $100 \mathrm{mg}(1.45 \mathrm{mg} /$ $\mathrm{kg})$ および $200 \mathrm{mg}(2.7 \mathrm{mg} / \mathrm{kg})$, イヌに $3 \mathrm{mg} / \mathrm{kg}$ の 経口投与で血中の $\mathrm{TXB}_{2}$ 産生は $90 \%$ 以上抑制され, 投 与 60 分後で最大であること ${ }^{15,20)}$ また， dazoxiben お よび imidazole 誘導体の UK-34,387 の AA 凝集阻害 には responder と non-responder のあること年,22)な どが報告されているが, dazoxiben の血小板凝集阻害 効果については明確でない. 本実験でも Randall ら ${ }^{15)}$ および Tyler ら 23) の報告から $\mathrm{TXA}_{2}$ 産生をほぼ完全 に阻害すると考兄られる $10 \mathrm{mg} / \mathrm{kg}$ をモルモットに経口 投与したが 60 分後の血小板凝集には何ら影響なかった. さらに, $300 \mathrm{mg} / \mathrm{kg}$ に増量しても全く阻害を示さなか った. 従って, 本実験条件では dazoxiben は血小板凝 集を阻害しないと結論される.

S-145 は強力な血小板凝集阻害を示すが, ONO-3708 や SQ 29,548 にはみられない部分アゴニスト作用を有 している ${ }^{23)}$. 事実, ヒト, マウス, ラット, ウサギおよ びモルモットの PRP に S-145を $0.1 \sim 0.8 \mu \mathrm{M}$ (終濃 度）添加すると血小板の形態变化に対応する透光度の減 
少がみられた.

このような変化はモルモットが最も鋭敏で，次いで， ラット拈よびマウス，ヒト拈よびウサギの順に低下し た.

そこで，モルモットPRP に S-145 $(0.2 \mu \mathrm{M}$ および $0.8 \mu \mathrm{M})$ を添加し形態変化の起った 5 分後に, 再度同濃 度の S-145を添加したが透光度には全く变化はみられ なかった.ささらに, 形態変化を示さない低濃度 $(0.025$ $\mu \mathrm{M})$ の S-145 を繰返し添加し, 4 回めの添加で, 単回 添加なら形態变化を示す濃度の $0.2 \mu \mathrm{M}$ を添加しても透 光度の変化, すなわち形態変化は招来されなかった，従 って，S-145 の部分アゴニスト作用は低用量の前処置で 消失するので, 緩除に吸収される投与方式により軽減ま たは消失させることが可能ではないかと考兄られる.

以上の如く，S-145 は in vitro および ex vivo で も血小板の凝集を阻害し, 特にモルモットに経口投与し た場合には ONO-3708 おょび SQ 29,548 よりも強い 阻害作用を示した. 従って, S-145 は経口的に抗血小板 薬として有用な化合物であると考兄られる.

謝辞 : 本研究を実施するに当り, 各種化合物を合成して いただいた当研究所の成定昌幸, 大谷光昭, 渡辺文彦, 萩下山治の各氏に感謝致します。

\section{文献}

1) Svensson, J., Hamberg, M. and Samuelsson, B.: Acta Physiol. Scand. 98, 285 (1976)

2) Ogletree, M.L.: Fed. Proc. 46, 133 (1987)

3) Svensson, J., Strandberg, K., Tuvemo, T. and Hamberg, M.: Prostaglandins 14, 425 (1977)

4) Halushka, P.V. and Lefer, A.M.: Fed. Proc. 46, 131 (1987)

5) Lewy, R.I., Wiener, L., Walinsky, P., Lefer, A.M., Silver, M.J. and Smith, J.B.: Circulation 61, 1165 (1980)

6) Mitchell, J.R.A.: Br. Med. Bulletin 39, 289 (1983)
7) Narisada, M., Ohtani, M., Watanabe, F., Uchida, K., Arita, H., Doteuchi, M., Hanasaki, K., Kakushi, H., Otani, K. and Hara, S.: J. Med. Chem. 31, 1847 (1988)

8) Hanasaki, K. and Arita, H.: Biochem. Pharmacol. 37, 3923 (1988)

9) Hanasaki, K. and Arita, H.: Thromb. Res. 50, 365 (1988)

10) Hanasaki, K., Nakano, K., Kasai, H., Arita, H., Ohtani, K. and Doteuchi, M.: Biochem. Biophys. Res. Commun. 150, 1170 (1988)

11) Hanasaki, K., Nakano, K., Kasai, H., Kurihara, H. and Arita, H.: Biochem. Biophys. Res. Commun. 151, 1352 (1988)

12) Suga, H., Hamanaka, N., Kondo, K., Miyake, H., Ohuchida, S., Arai, Y. and Kawasaki, A.: 6th Int. Conf. on Prostaglandin and Related Compounds, Florence, Abstract, p. 331 (1986)

13) Ogletree, M.L., Harris, D.N., Greenberg, R., Haslanger, M.F. and Nakane, M.: J. Pharmacol. Exp. Ther. 234, 435 (1985)

14) Vane, J.R.: Nature (new biol.) 231, 232 (1971)

15) Randall, M.J., Parry, M.J., Hawkeswood, E., Cross, P.E. and Dickinson, R.P.: Thromb. Res. 23, 145 (1981)

16) Born, G.V.R.: Nature 194, 927 (1962)

17) Uchida, K., Nakamura, M., Konishi, M., Ishigami, T. and Komeno, T.: Japan. J. Pharmacol. 43, 9 (1987)

18) Kattelman, E.J., Venton, D.L. and Le Breton, G.C.: Thromb. Res. 41, 471 (1986)

19) Narumiya, S., Okuma, M. and Ushikubi, F.: Br. J. Pharmacol. 88, 323 (1986)

20) Tyler, H.M., Saxton, C.A.P.D. and Parry, M.J.: Lancet i, 629 (1981)

21) Bertele, V., Cerletti, G., Schieppati, A., Di Minno, G. and De Gaetano, G.: Lancet i, 1057 (1981)

22) Heptinstall, S., Bevan, J., Cockbill, S.R., Hanley, S.P. and Parry, M.J.: Thromb. Res. 20, 219 (1980)

23) Nakano, K., Hanasaki, K. and Arita, H.: FEBS Lett. 234, 309 (1988) 
Abstract-Effect of a new thromboxane $\mathrm{A}_{2}$ antagonist, S-145, on platelet aggregation.
Hisato KAKUSHI, Tsutomu SHIKE and Kiyohisa UCHIDA (Shionogi Research Labora-
tories, Shionogi \& Co., Ltd., Fukushima-ku, Osaka 553, Japan). Folia pharmacol. japon.
93, 171 178 (1989) The newly synthesized compound S-145, ( \pm ) -5 (Z) -7- (3-endo-phenylsulfonylamino [2.2.1] bicyclohept-2-exo-yl)heptenoic acid, inhibited arachidonic acid (AA)-, 9,11-methanoepoxy$\mathrm{PGH}_{2}$ (U46619)-, collagen- and ADP-induced human platelet aggregation in vitro with IC50 values of $0.25,0.34,0.22$, and $0.08 \mu \mathrm{M}$, respectively. The inhibiting potency of this compound to AA- or U46619-induced platelet aggregation was about twice that of ONO3708 and $1 / 7 \sim 1 / 14$ that of SQ29,548 in human platelets, about 7 times that of ONO-3708 and $1 / 3 \sim 1 / 7$ that of SQ29,548 in guinea pig platelets, and $250 \sim 800$ times that of ONO-3708 and 1 7 times that of SQ29,548 in rabbit platelets. When S-145 was administered orally to guinea pigs at the dose of $0.1 \mathrm{mg} / \mathrm{kg}$, AA-induced platelet aggregation was completely inhibited at 30 and 60 min after the administration, but not at 3 and $6 \mathrm{hr}$. The minimum effective doses of S-145 (p.o.) to AA- and collagen-induced platelet aggregation at $60 \mathrm{~min}$ after the administration were $0.01 \mathrm{mg} / \mathrm{kg}$ and $0.03 \mathrm{mg} / \mathrm{kg}$, respectively. The potency of S-145 (p.o.) to inhibit AA- and collagen-induced guinea pig platelet aggregation was 30 300 times that of ONO-3708 or SQ29,548 and 300 1000 times that of aspirin. These results suggest that $\mathrm{S}-145$ is a thromboxane $\mathrm{A}_{2}$ antagonist showing a potent inhibiting effect on platelet aggregation by oral administration. 